\title{
MODIFIKASI DURASI CAMSHAFT UNTUK MENINGKATKAN PERFORMA MESIN SATU SILINDER 115 CC
}

\author{
Irwan Tri Prasetyo \\ Fakultas teknik, Jurusan Teknik Mesin \\ Universitas Sultan Ageng Tirtayasa \\ Email: Prasetyo2517@gmail.com \\ Agung Sudrajad \\ Jurusan Teknik Mesin \\ Universitas Sultan Ageng Tirtayasa \\ Email : Agung@untita.co.id \\ Yusvardi Yusuf \\ Jurusan Teknik Mesin \\ Universitas Sultan Ageng Tirtayasa \\ Email : babayusvardi@yahoo.com
}

\begin{abstract}
ABSTRAK
Performa mesin yang kurang maksimal pada motor standar mengharuskan pengguna motor memodifikasi sektor mesin, salah satunya pada durasi camshaft. Penelitian ini bertujuan untuk meningkatkan performa motor dengan memodifikasi durasi camshaft. Pelaksanaan penelitian dilakukan di Laboraturium Motor Bakar Jurusan Teknik Mesin Fakultas Teknik Universitas Sultan Ageng Tirtayasa . Modifikasi dilakukan dengan merubah durasi camshaft dan lobe separation angle (LSA), dimana durasi camshaft standart pada katup intake $221^{\circ}$ dan lobe separation angle $96.75^{\circ}$ serta katup exhaust $202^{\circ}$ lobe separation angle $84^{\circ}$. Modifikasi camshaft ke-satu dengan durasi katup intake $235^{\circ}$ dan lobe separation angle $100.5^{\circ}$ serta katup exhaust $235^{\circ}$ dengan lobe separation angle (LSA) $102,5^{\circ}$ yang akan dibandingkan dengan modifikasi camshaft ke-dua dengan durasi katup intake $260^{\circ}$ dan lobe separation angle (LSA) $104^{\circ}$ serta katup exhaust durasi $260^{\circ}$ dengan lobe separation angle $107^{\circ}$ ). Hasil penelitian ini menunjukan bahwa performa mesin terbaik yakni menggunakan modifikasi camshaft ke-dua. Peningkatan torsi pada modifikasi camshaft adalah 19,182 \% dan 22,902\% untuk modifikasi satu dan dua secara berturut-turut terhadap camshaft standar. Untuk peningkatan daya modifikasi camshaft terhadap camshaft standar adalah 7,378\% dan 13,45\% untuk modifikasi satu dan dua secara berturut-turut.
\end{abstract}

Kata kunci : Motor, Performa, Modifikasi Camshaft , Lobe Separation Angle (LSA).

\begin{abstract}
The performance that is not optimal on a standard motorcycle requires users to do modification on the engine sector. The objective of this research was to improve motorcycle performance by modifying the camshaft duration. The research conducted at Motorcycle Combustion Laboratories Of Engineering Faculty Of Sultan Ageng Tirtayasa University. The modification conducted by changing the camshaft duration and the Lobe Separation Angle (LSA) where the standard of camshaft duration on valve intake was $221^{\circ}$ with the Lobe Separation Angle (LSA) was 96.75․ The valve exhaust was $202^{\circ}$ with lobe separation angle was $84^{\circ}$. The Camshaft duration on the first modification where valve intake was $235^{\circ}$ and the lobe separation angle was $100.5^{\circ}$ and valve exhaust was $235^{\circ}$ and the lobe separation angle was 102.5 . Meanwhile, the camshaft duration on the second modification was valve intake was $260^{\circ}$ and lobe separation $104^{\circ}$ and valve exhaust duration were $260^{\circ}$ and lobe separation angle $107^{\circ}$. On the first test by using camshaft duration first modification, the torque was increased $19.182 \%$ than using standard camshaft. In the second testing by using the second modified camshaft duration, the torque was increased $22.902 \%$ compared with the standard camshaft. On the other hand, the power of first modification camshaft with the standard camshaft was $7.378 \%$, the second modification camshaft with the standard camshaft is $13.45 \%$ and the rate of fuel consumption on the standard camshaft with the first modification was $15 \%$ and on the standard
\end{abstract}

84 Modifikasi Durasi Chamshaft... (I. T. Prasetyo, A. Sudrajad, Y. Yusuf) 
camshaft with the second modification was $15 \%$. The results of this research indicated the best engine performance using a second modified camshaft duration.

Keywords: Motor, Performance, Camshaft Modification, Lobe Separation Angle (LSA).

\section{PENDAHULUAN}

Di era modern ini, transportasi merupakan sarana yang dibutuhkan oleh masyarakat. Seiring dengan perkembangan zaman, kebutuhan akan transportasi selalu meningkat khususnya kendaraan sepeda motor. Hal ini diperkuat oleh data Badan pusat statistik yang menyatakan bahwa pada tahun 2018 sudah tercatat 120.101.047 kendaraan sepeda motor di indonesia [1]. Hal tersebut diikuti pula dengan perkembangan teknologi kendaraan. Kendaraan yang diproduksi oleh perusahaan manufaktur umunya sudah melalui tahap perancangan dan pengujian sehingga memnuhi standar layak pakai seperti keamanan dan kenyamanan. Namun pada sebagian pengguna sepeda motor sering kali performa mesin bawaan pabrik (standard engine) masih dirasa kurang maksimal, sehingga membuat pengguna sepeda motor memutuskan untuk melakukan modifikasi di sektor mesin untuk meningkatkan performa.

Salah satu langkah yang dapat dilakukan untuk meningkatkan performa mesin sepeda motor dapat dilakukan dengan memaksimalkan kinerja sistem camshaft. Torsi yang dihasilkan oleh motor berbanding lurus dengan penambahan kecepatan (RPM) serta daya (Power) yang diberikan untuk meningkatkan performa mesin [2]. Dengan merubah durasi dan menambah tinggi bukaan katup maka performa mesin motor akan meningkat [3]. Merubah durasi pada camshaft ini bertujuan untuk mengubah waktu membuka dan menutupnya katup yang bertujuan untuk meningkatkan efisiensi volumetrik, sedangkan pada Lobe Separation Angle (LSA) perubahan akan divariasi dengan tujuan untuk meningkatkan power pada putaran atas [4]. Salah satu cara untuk mendapatkan efisiensi volumetric yang maksimal sehingga dapat menghasilkan tenaga seoptimal mungkin adalah dengan melakukan modifikasi pada camshaft [5].

Memodifikasi sistem kerja camshaft dilakukan dengan mengubah durasi dan lobe separation angle (LSA) untuk meningkatkan performa mesin. Namun, perubahan durasi dan Lobe Separation Angle (LSA) pada setiap camshaft tidak selamanya berbanding lurus dengan torsi dan RPM yang diperoleh [6]. Hal tersebut menyebabkan munculnya produk aftermarket di pasar otomotif dengan pelbagai merek yang tidak memberikan hasil yang maksimal. Hasil pengujian kekerasan camshaft standar lebih tinggi 30\% dibanding dengan camshaft aftermarket, hal ini dipengaruhi struktur mikro camshaft standar berbentuk grafit lebih rapat dan halus dibandingkan camshaft aftermarket [7]. Saat ini, modifikasi durasi dan Lobe Separation Angle (LSA) dilakukan dengan mendesain menggunakan software dan dikerjakan oleh mesin Computer Numerical Control (CNC). Penelitian ini merujuk pada buku Alexander Graham Bell [8]. Penelitian ini dilakukan dengan tujuan meningkatkan performa mesin satu silinder empat langkah kapasitas $155 \mathrm{cc}$ dengan memodifikasi durasi dan LSA camshaft.

\section{METODE PENELITIAN}

Penelitian ini dilakukan pada Bulan September 2019 bertempatan di Laboraturium Motor Bakar Jurusan Teknik Mesin Fakultas Teknik Universitas Sultan Ageng Tirtayasa, dengan pengujian berupa mesin motor yang setiap empat langkah torak atau piston (dua putaran engkol) sempurna menghasilkan satu tenaga kerja atau bisa disebut juga dengan motor bensin empat langkah [9]. 


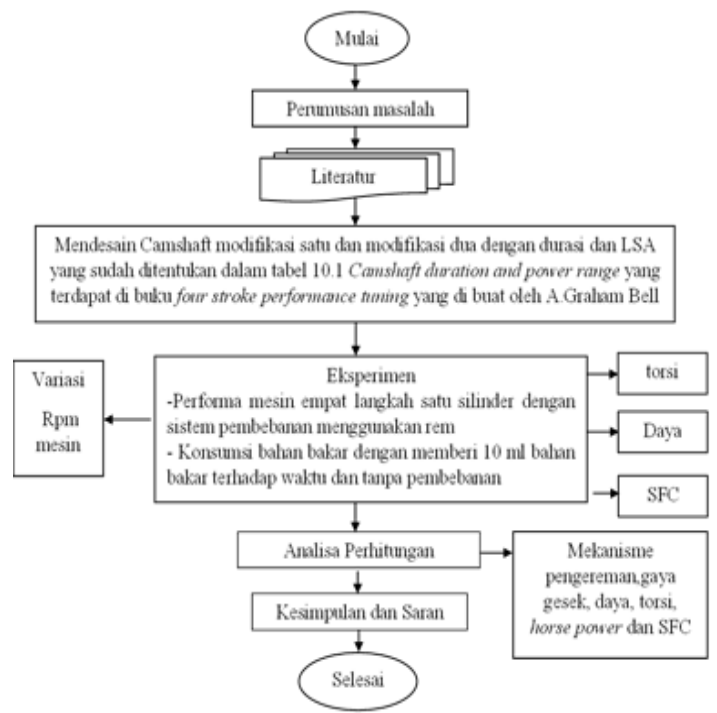

Gambar 1. Metode Penelitian

Penelitian dilakukan dengan metode uji eksperimental dengan membandingkan performa keluaran yang dihasilkan dari camshaft standar, camshaft modifikasi 1 dan camshaft modifikasi 2. Adapun performa yang dimaksud adalah daya dan torsi. Hasil performa diperoleh dengan pengujian nilai daya dan torsi pada RPM 2000, 4000, 6000 dan 8000 dengan pembebanan maksimum. Pembebanan dilakukan dengan mekanisme pengereman (braking system) yang telah di desain sehingga layak untuk dilakukan pengujian. Adapun alat dan bahan serta spesifikasi dari mesin uji adalah sebagai berikut.

Tabel. 1 Spesifikasi Mesin, alat dan bahan

\begin{tabular}{ll|c}
\hline & Spesifikasi Mesin & Alat dan Bahan \\
\hline Tipe Mesin & 4 Langkah, SOHC 2 Klep Van Cooler & Mesin Yamaha Mio J Produksi 2012 \\
Diameter x Langkah & $50.0 \times 57.9 \mathrm{~mm}$ & Tachometer \\
Volume Silinder & $115 \mathrm{cc}$ & Load Cell \\
Rasio Kompresi & $9.3: 1$ & Dial Indikator \\
Kapasitas Oli Mesin & 0.9 Liter & Toolkit \\
Bahan Bakar & Oktan 92 & Camshaft \\
\hline
\end{tabular}

\section{PERSAMAAN MATEMATIKA}

Tabel. 2 Persamaan matematika

\begin{tabular}{|c|c|c|}
\hline \multicolumn{3}{|c|}{ Rumus } \\
\hline Momen gaya pada handle & $\mathrm{F}_{1}=\mathrm{m} \times \mathrm{g}=\mathrm{N}$ & $\mathrm{T}=\mathrm{F}_{3} \times \mu \times \mathrm{kt} \times \mathrm{rm}$ \\
\hline Gaya Gesek Disk brake & $F_{\text {gesek }}=F 3 \times \mu$ & $\mathrm{P}=2 \pi \times \frac{N_{r e v}}{s} \times \mathrm{T} \times 10^{-3}$ \\
\hline Titik Tengah Gesekan & $\mathrm{rm}=\frac{(\mathbf{r b}+\mathbf{r k})}{2}$ & Konsumsi Bahan Bakar \\
\hline Gaya dorong pada piston Kaliver & $\mathrm{F}_{3}=\frac{F_{2} \times A_{2}}{A_{1}}$ & $\mathrm{k}=\frac{G \times d^{3}}{8 . N \cdot D^{\wedge} 2}$ \\
\hline Gaya dorong pada piston master rem & $F_{2}=\frac{T_{1}}{X_{2}}$ & \\
\hline
\end{tabular}


Tabel. 3 Notasi dan keterangan [10]

\begin{tabular}{|c|c|c|c|}
\hline Notasi & Keterangan & Notasi & Keterangan \\
\hline $\mathbf{n}$ & Putaran Mesin (rpm) & $\mathbf{X}_{1}$ & $\begin{array}{c}\text { Jarak handle rem dari poros ke } \\
\text { ujung handle }(\mathrm{m})\end{array}$ \\
\hline $\mathbf{P}$ & Daya Mesin (hp) & $\mathbf{m}$ & $\begin{array}{l}\text { Beban yang dihasilkan oleh } \\
\text { timbangan digital }(\mathrm{kg})\end{array}$ \\
\hline $\mathbf{T}$ & Torsi $(\mathrm{Nm})$ & $\mathbf{g}$ & Gravitasi $\left(9,8 \mathrm{~m} / \mathrm{s}^{2}\right)$ \\
\hline Sfc & Konsumsi Bahan Bakar Spesifik (gr/kWh) & $\mathbf{G}$ & Modulus geser baja (Gpa) \\
\hline $\mathbf{p}$ & Tekanan pada hidrolik & $\mathbf{K}$ & Konstanta pegas \\
\hline $\mathbf{F}_{1}$ & Gaya pengereman pada handle $(\mathrm{N})$ & d & Tebal pegas master rem $(\mathrm{m})$ \\
\hline $\mathbf{F}_{2}$ & Gaya dorong pada piston master rem $(\mathrm{N})$ & $\mathbf{D}$ & Diameter pegas master rem (m) \\
\hline $\mathbf{F}_{3}$ & $\begin{array}{l}\text { Gaya pengereman pada pendorong piston } \\
\text { kampas rem }(\mathrm{N})\end{array}$ & $\mathbf{N}$ & Jumlah gulungan pegas master rem \\
\hline $\mathbf{X}_{1}$ & $\begin{array}{l}\text { Jarak handle rem dari poros ke ujung } \\
\text { handle }(\mathrm{m})\end{array}$ & $\mathbf{F}_{\text {pegas }}$ & Gaya pegas $(\mathrm{N})$ \\
\hline $\mathbf{X}_{1}$ & $\begin{array}{c}\text { Jarak handle rem dari poros ke penekan } \\
\text { piston master rem }(\mathrm{m})\end{array}$ & $\mathbf{F}_{1}$, & Gaya maksimal pada rem $(\mathrm{N})$ \\
\hline sfc & Konsumsi Bahan Bakar Spesifik (gr/kWh) & $\mathbf{A}_{1}$ & Luas piston master rem $\left(\mathrm{m}^{2}\right)$ \\
\hline
\end{tabular}

\section{HASIL DAN PEMBAHASAN}

Pengujian dilakukan dengan metode pembebanan melalui pengereman (handel rem) pada setiap rpm dan pada setiap camshaft. Data hasil pengujian kemudian diolah sehingga memperoleh grafik sebagai berikut.

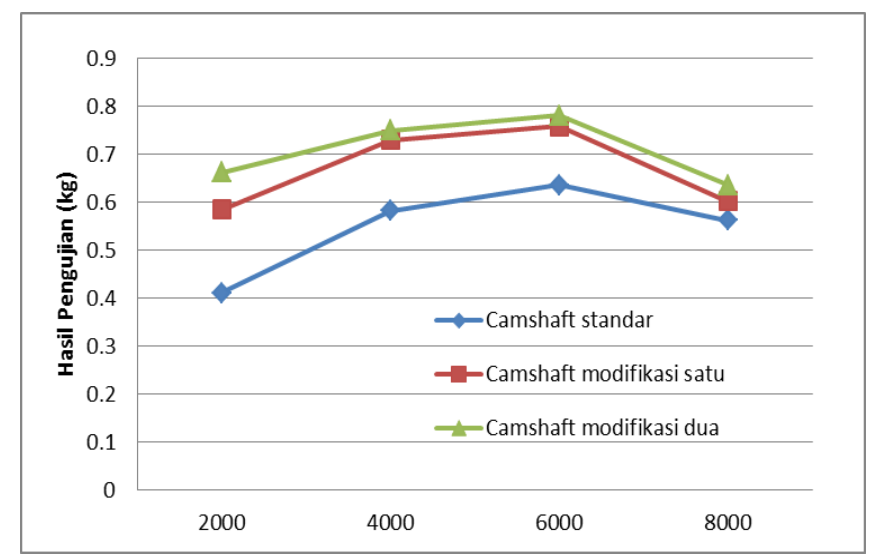

\section{Gambar 2 Grafik perbandingan gaya yang dihasilkan handle rem antara camshaft standar, camshaft modifikasi 1 dan camshaft modifikasi 2 terhadap putaran mesin (rpm)}

Pada gambar 2 grafik perbandingan gaya yang dihasilkan handle rem antara camshaft standar, camshaft modifikasi 1 dan camshaft modifikasi 2 terhadap putaran mesin (rpm) dapat dilihat bahwa gaya puncak untuk semua jenis camshaft terjadi di rpm 6000. Hal ini menandakan bahwa performa mesin terbaik ada pada putaran $6000 \mathrm{rpm}$. Namun yang menarik adalah, peningkatan gaya yang dihasilkan tiap rpm pada camshaft modifikasi 1 dan modifikasi 2. Peningkatan gaya menunjukkan peningkatan performa mesin yaitu daya atau torsi [7]. Camshaft modifikasi 1 mengalami peningkatan sebesar 50\% di rpm 2000, 22\% di rpm 4000, 22,6\% di rpm 6000 dan 3,5\% di rpm 8000 jika dibandingkan dengan camshaft standar. Sedangkan camshaft modifikasi 2 mengalami peningkatan sebesar $65 \%$ di rpm 2000, 25,4\% di rpm 4000, 23,8\% di rpm 6000 dan 8,6\% di rpm 8000 .

Peningkatan gaya pada camshaft modifikasi 2 disebabkan oleh sudut durasi camshaft yang tinggi yang mengakibatkan waktu bukaan klep (valve) menjadi lama, sehingga bahan bakar dan udara yang terkarburasi masuk ke ruang bakar dengan kubikasi yang lebih besar mengakibatkan pembakaran menjadi lebih sempurna. 
Dari data gaya handle di atas dapat digunakan untuk mengetahui daya dan torsi motor , berikut grafik yang menggambarkan daya dan torsi motor dari setaip camshaft.

a. Daya dan torsi pada camshaft standar, modifikasi satu dan modifikasi dua

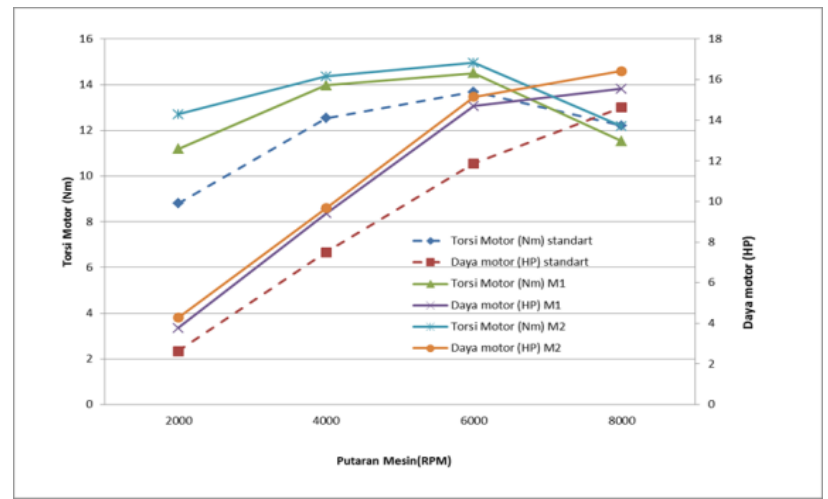

\section{Gambar 3. Grafik perbandingan daya dan torsi yang dihasilkan oleh camshaft standar, camshaft modifikasi 1 dan camshaft modifikasi 2 pada setiap putaran (rpm)}

Gambar 3 menggambarkan grafik perbandingan daya dan torsi yang dihasilkan oleh camshaft standar, camshaft modifikasi 1 dan camshaft modifikasi 2 pada setiap putaran mesin (rpm). Grafik tersebut menunjukan peningkatan daya dan torsi pada camshaft modifikasi 1 dan 2 terhadap camshaft standar.

Berdasarkan grafik, camshaft modifikasi 1 menghasilkan peningkatan daya sebesar 30,1\% di rpm 2000, 20,3\% di rpm 4000, 19,3\% di rpm 6000 dan 5,9\% di rpm 8000 terhadap camshaft standar. Sedangkan untuk camshaft modifikasi 2 mengalami peningkatan daya (Hp) sebesar 38,4\% di rpm 2000, 22,5\% di rpm 4000, $21,7 \%$ di rpm 6000, dan 10,9\% di rpm 8000. Begitupun dengan nilai torsinya. Torsi yang dihasilkanpun ikut meningkat. Berdasarkan grafik di atas, camshaft 1 mengalami peningkatan nlai torsi sebesar 30,\% di rpm 2000 , 20,3\% di rpm 4000, 16,1\% di rpm 6000, dan 5,9\% di rpm 8000 jika dibandingkan dengan camshaft standar. Sedangkan untuk camshaft 2, nilai torsi mengalami peningkatan sebesar 38,4\% di rpm 2000, 22,4\% di rpm 4000, $18,6 \%$ di rpm 6000 dan 10,9\% di rpm 8000.

Peningkatan nilai daya dan torsi disebabkan oleh durasi camshaft yang memiliki sudut bukan yang besar. Camshaft modifikasi 2 dengan durasi camshaft tinggi memungkinkan klep masuk (valve in) membuka lebih lama, sehingga jumlah cc/unit antara bahan bakar dan udara yang terkarburasi masuk ke ruang bakar lebih besar, mengakibatkan pembakaran lebih sempurna. Berikut tabel perbandingan daya dan torsi setiap camshaft.

Tabel 4. Perbandingan nilai Daya (Hp) tiap camshaft

\begin{tabular}{cccc|cc}
\hline \multirow{2}{*}{ RPM } & \multicolumn{3}{c}{ Daya (Horse Power) } & \multicolumn{2}{c}{ Peningkatan Daya (\%) } \\
\cline { 2 - 6 } & $\begin{array}{c}\text { Camshaft } \\
\text { Standar }\end{array}$ & $\begin{array}{c}\text { Camshaft } \\
\mathbf{1}\end{array}$ & $\begin{array}{c}\text { Camshaft } \\
\mathbf{2}\end{array}$ & $\begin{array}{c}\text { Cam std VS } \\
\text { Cam 1 }\end{array}$ & $\begin{array}{c}\text { Cam std VS } \\
\text { Cam 2 }\end{array}$ \\
\hline 2000 & 2.63 & 3.76 & 4.27 & 30.1 & 38.4 \\
4000 & 7.49 & 9.4 & 9.66 & 20.3 & 22.5 \\
$\mathbf{6 0 0 0}$ & $\mathbf{1 1 . 8 6}$ & $\mathbf{1 4 . 6 9}$ & $\mathbf{1 5 . 1 5}$ & $\mathbf{1 9 . 3}$ & $\mathbf{2 1 . 7}$ \\
8000 & 14.62 & 15.53 & 16.41 & 5.9 & 10.9 \\
\hline
\end{tabular}


Tabel 5. Perbandingan nilai Torsi (Nm) tiap camshaft

\begin{tabular}{cccc|cc}
\hline \multirow{2}{*}{ RPM } & \multicolumn{3}{c}{ Torsi $(\mathbf{N m})$} & \multicolumn{2}{c}{ Peningkatan Torsi (\%) } \\
\cline { 2 - 6 } & $\begin{array}{c}\text { Camshaft } \\
\text { Standar }\end{array}$ & $\begin{array}{c}\text { Camshaft } \\
\mathbf{1}\end{array}$ & $\begin{array}{c}\text { Camshaft } \\
\mathbf{2}\end{array}$ & $\begin{array}{c}\text { Cam std VS } \\
\text { Cam 1 }\end{array}$ & $\begin{array}{c}\text { Cam std VS } \\
\text { Cam 2 }\end{array}$ \\
\hline 2000 & 8.8 & 12.58 & 14.28 & 30.0 & 38.4 \\
4000 & 12.53 & 15.72 & 16.14 & 20.3 & 22.4 \\
$\mathbf{6 0 0 0}$ & $\mathbf{1 3 . 6 8}$ & $\mathbf{1 6 . 3}$ & $\mathbf{1 6 . 8 1}$ & $\mathbf{1 6 . 1}$ & $\mathbf{1 8 . 6}$ \\
8000 & 12.2 & 12.97 & 13.7 & 5.9 & 10.9 \\
\hline
\end{tabular}

Berdasarkan tabel di atas, nilai torsi dan daya terbaik dihasilkan oleh camshaft modifikasi 2 yaitu 16,81 Nm dan 15,15HP di rpm 6000.

b. Konsumsi bahan bakar camshaft standar, modifikasi 1 dan modifikasi 2

Dari data daya yang diperoleh, dapat dicari nilai konsumsi bahan bakar spesifik setiap rpm. Berikut grafik yang menggambarkan nilai konsumsi bahan bakar setiap putaran (rpm) pada masing-masing camshaft.

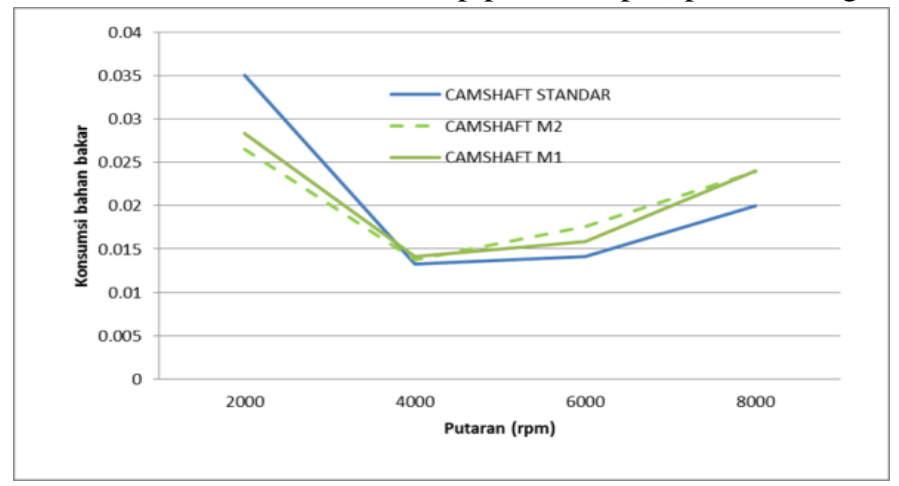

\section{Gambar 4 Grafik konsumsi bahan bakar}

Pada grafik, dapat di lihat perbandingan nilai konsumsi bahan bakar setiap setiap putaran (rpm) pada masing-masing camshaft. Camshaft 2 memiliki grafik yang lebih stabil dibandingkan camshaft standar dan camshaft modifikasi 1. Durasi camshaft menentukan kapan terjadinya langkah hisap, langkah kompresi, langkah kerja dan langkah buang. Durasi (timing) yang pas akan menentukan penggunaan konsumsi bahan bakar dan performa yang dihasilkan lebih maksimal. Jika dilihat dalam grafik, camshaft modifikasi 2 memiliki rate konsumsi bahan bakar yang lebih stabil dan performa yang dihasilkan lebih besar. Hal ini disebabkan oleh durasi pada camshaft modifikasi 2 ada pada sudut yang tepat, sebab jika sudutnya berlebihan yang terjadi adalah udara dan bahan bakar yang masuk berlebihan (rich) menyebabkan pembakaran tidak sempurna, dan performa yang dihasilkan menurun.

\section{KESIMPULAN}

Dari hasil analisa data dan perhitungan yang telah dilakukan, dapat diambil kesimpulan sebagai berikut.

1. Dengan memodifikasi camshaft, maka performa mesin akan meningkat. Hal itu disebabkan oleh perubahan durasi dan Lobe Separation Angle (LSA) pada setiap camshaft. Peningkatan torsi pada camshaft modifikasi satu dengan camshaft standar adalah 16,1\% di putaran 6000 dan camshaft modifikasi dua dengan camshaft standar sebesar 18,6 \% diputaran 6000. sedangkan peningkatan daya camshaft modifikasi satu dengan camshaft standar adalah 19,3\%, dan camshaft modifikasi dua dengan camshaft standar sebesar $21,7 \%$ pada putaran 6000. Dari hasil persentase torsi dan daya dapat disimpulkan bahwa performa mesin terbaik menggunakan camshaft modifikasi dua.

2. Hasil percobaan konsumsi bahan bakar dengan menggunakan camshaft standar, camshaft modifikasi 1 dan 2 menunjukkan bahwa hasil modifikasi camshaft dapat menurunkan konsumsi bahan bakar di putaran bawah (2000-4000 rpm) dan kenaikan konsumsi bahan bakar di putaran atas (4000-8000 rpm). Hal ini diakibatkan oleh turbulensi, karburasi (pengkabutan) serta pembakaran bahan bakar dan udara lebih sempurna. 


\section{DAFTAR PUSTAKA}

[1] Badan pusat statistik. (2020). Perkembangan Jumlah Kendaraan Bermotor Menurut Jenis. [Online]. Available: https://www.bps.go.id/linkTableDinamis/view/id/1133.

[2] Irashi, Zidni.(2018).Uji Performa Generator Listrik Berpenggerak Motor Diesel Satu Silinder Di Laboraturium Fakultas Teknik Untirta.p39.

[3] Kristanto, Dwi. (2017). Pengaruh perubahan durasi camshaft terhadap performance mesin FD 110 cc.p57

[4] Anam Choirul, M, dan Muhaji. (2018). Pengaruh Variasi Perubahan Kontur CamshaftTerhadap Unjuk Kerja Pada Honda Megapro 160D Advanced.p86.

[5] Stevansa, Adrianto Priyo. (2014).Pengaruh Penggunaan Camshaft Standar dan Camshaft Racing Terhadap Unjuk Kerja Motor Bensin Empat Langkah”.p2.

[6] Alam, Perkasa Teguh. (2014). Analisa Unjuk Kerja Mesin Diesel Kapasitas 132cc pada Prototipe CulaSatu Untitra.p30.

[7] Pudjanarsa, Astu., and Nursuhud, Djati. (2006) Mesin Konversi Energi.Yogyakarta: C.V ANDI OFFSET

[8] Graham bell, Alexander.(1981). Performance tuning in theory and practice four stroke. England :Haynes Publising Group

[9] Abdillah, Aini dan Supriyanto.(2011).Tinjauan Ketahanan Aus Hasil Modifikasi Noken As Pada Motor Balap.p116.

[10] Sularso, Ir., and Suga, Kiyokatsu. (2008). Dasar perancangan dan pemilihan Elemen Mesin. Bandung : PT Pradnya Paramita. p318. 